\title{
Aleksandra Naróg
}

\section{„Wegetatywne i telluryczne ingrediencje". Obraz wstrętu w opowiadaniach Sierpień i Pan Brunona Schulza}

\begin{abstract}
„Vegetative and Telluric Ingredients”. Repulsion in the Short Stories August and Pan by Bruno Schulz

This paper is an attempt to investigate two short stories by Bruno Schulz (August and Pan) in the context of repulsion. This phenomenon was presented as an esthetical, ontological and epistemological determinant of Modernist literature. The experience of disgust was interpreted according to the elements of theoretical thought by Julia Kristeva and Mary Douglas as well as the affective turn in the humanities. It was found out that repulsion may be analysed as the main part of „topography” of Schulz's universe: one of its main principles, both forming and deconstructing its matter.
\end{abstract}

Słowa kluczowe: wstręt, Sierpień, Pan, Julia Kristeva, Mary Douglas

Keywords: repulsion, August, Pan, Julia Kristeva, Mary Douglas

Doświadczenie wstrętu znajdowało w ciągu wieków swoje różnorodne interpretacje zarówno w refleksji filozoficznej, jak i literackiej. W ujęciu Winnfrieda Menninghausa jest ono „,[...] jednym z najbardziej gwałtownych afektów, do jakich jest zdolny ludzki system percepcji”'. Refleksja nad wstrętem pojawiała się już w myśli Immanuela Kanta, określającego go mianem „potężnego doznania witalnego ${ }^{2 " ; ~ F r y d e r y k ~ N i e t z s c h e ~ z ~ k o l e i ~ u z n a w a ł ~ t o ~}$

${ }^{1}$ W. Mennninghaus, Wstręt. Teoria i historia, przeł. G. Sowinski, Kraków 2009, s. 7.

2 Por. I. Kant, Antropologia w ujęciu pragmatycznym, s. 49. Cyt. za: W. Menninghaus, op.cit., s. 7. 
doświadczenie za rodzaj wynikającej ze znużenia „tragedii poznania”, podlegającej przezwyciężeniu jedynie przez przyjęcie postawy afirmatywnej ${ }^{3}$. W psychoanalizie Freudowskiej stanowi ono jeden z koniecznych elementów warunkujących przejście od stanu natury do kultury. To: ,neurotyczny [...] system wyparcia archaicznych pobudzeń instynktownych, [...] efekt sublimacji i narzędzie zakazów cywilizacyjnych" ". Sara Ahmed opisuje natomiast wstręt jako doświadczenie oddziałujące w silny sposób na cielesność, podważające stałość opozycji pomiędzy wnętrzem a zewnętrzem ${ }^{5}$. Menninghaus zwraca uwagę na szczególną rolę awersji, polegającą na zakwestionowaniu ustalonego statusu ontologicznego podlegającego mu podmiotu:

Gdy odczuwamy wstręt, wszystko zdaje się zagrożone. [...] Jest stanem alarmowym i stanem wyjątkowym, ostrym kryzysem w obliczu niedającej się asymilować inności, konwulsją i walką, w której literalnie chodzi o „być albo nie być”.

Jego działanie opiera się na opozycji asymilacji i oddalenia, nieustannie przesuwającej granice pomiędzy tym, co „,przyswajalne” i „wykluczane”.

Julia Kristeva w eseju Potęga obrzydzenia opisuje literackie reprezentacje wstrętu, wywodząc swoją koncepcję z myśli psychoanalitycznej Freuda, w której ,ja” oparte na doznaniu rozkoszy „włącza” w siebie wszystko, co dobre, a odrzuca to, co złe ${ }^{7}$. Interpretując elementy twórczości najwybitniejszych prozaików XIX i XX wieku - między innymi Dostojewskiego, Prousta czy Céline'a - uznaje za jedną z funkcji literatury:

[...] zapuszczanie korzeni w tej delikatnej granicy [...], gdzie tożsamości jeszcze nie ma lub są ledwie zarysowane - podwójne, płynne, niejednorodne, zwierzęce, przemienione, zniekształcone, wstrętne ${ }^{8}$.

Wstręt jest doświadczeniem ,pragnienia, które nie pozwala się uwieść”, „granicą nieistnienia i halucynacji”" „Nieuchwytny” element kwestionujący status podmiotowości autorka określa przez pojęcie abiektu [abject], które definiuje jako „to, co znajduje się blisko”, ale „nie daje się przyswoić”; to, co „narzucając się”, jednocześnie „niepokoi i fascynuje”. Abiekt znajduje się

3 Por. F. Nietzsche, Zur Genealogie der Moral, KSA, t. V, s. 366 [Z genealogii moralności, s. 128, przekład zmieniony]. Cyt. za: W. Menninghaus, op.cit., s. 194.

4 Por. Z. Freud, Drei Abhandlungen zur Sexualtheorie [Życie seksualne, cytat niezlokalizowany], s. 78. Cyt. za: W. Menninghaus, op.cit., s. 9.

5 Por. S. Ahmed, Performatywność obrzydzenia, przeł. A. Barcz, „Teksty Drugie” 2014, nr 1, s. 173.

6 Ibidem.

7 W. Menninghaus, op.cit., s. 444.

8 J. Kristeva, Potęga obrzydzenia. Esej o wstręcie, przeł. M. Falski, Kraków 2007, s. 193.

9 Ibidem, s. 8. 
poza relacją podmiotowe - przedmiotowe, nie należy ani do sfery ciała, ani przestrzeni rzeczy, w niepokojący sposób będąc zawsze „,pomiędzy"10.

Wstręt ma swoje odzwierciedlenie w filozofii literackiej oraz prozie Brunona Schulza. Jego złożone reprezentacje obecne są niemal w każdym z opowiadań autora Sklepów cynamonowych; pojawiają się również w jego tekstach eseistycznych i krytycznoliterackich, listach oraz grafikach. Wydaje się stanowić jedną z podstaw proponowanej przez pisarza antropologii i epistemologii; jest również często wykorzystywaną kategorią estetyczną, pozwalającą na dokonanie wnikliwego opisu mechanizmów interakcji zachodzących pomiędzy bohaterami a światem. Awersja każdorazowo podszyta jest tu fascynacją, konstruując doświadczenie formujące status ontologiczny postaci oraz skłaniające do refleksji nad płynną opozycją natury i kultury. Wstręt staje się także jedną ze strategii konstrukcji kategorii podmiotowości i cielesności, podlegających nieustannym zabiegom transgresji i dezintegracji; często towarzyszy procesowi wyłaniania się tożsamości słów i przedmiotów. Związany jest z metaforyczną „eksplozją": wybuchami i nieustannym ,przelewaniem się” materii życia, w wyniku których opisywany świat zostaje niejako „rozsadzony” od wewnątrz. Jak pisze Kristeva:

We wstręcie przejawia się jeden z owych gwałtownych i mrocznych buntów bytu przeciw temu, co mu zagraża i co [...] nadchodzi z zewnątrz lub rozsadza od wewnątrz, rzucone obok tego, co dopuszczalne, tolerowane, możliwe do pomyślenia ${ }^{11}$.

Powyższe ujęcie pozwala zinterpretować wstręt w kategoriach doświadczenia afektywnego - jednej z głównych inspiracji dla współczesnych badań literackich oraz lektury postmodernistycznych tekstów kultury. Wydaje się, że przez równoczesną diagnozę wielu problemów modernizmu może stać się ono interesującym punktem wyjścia do ponownej lektury tekstów wcześniejszych - wyrażających procesy ,przeobrażającej się” materialności, ,płynności" materii i przekroczenia formy. Jak zauważa Ryszard Nycz, pozwala ono zastąpić ,wysterylizowany obraz klasycznego podmiotu [...] wizją jednostki o charakterze ucieleśnionym", poddanej różnorodnym literackim reprezentacjom; zarówno otwartej na wpływy, jak i nieustannie je wywołującej ${ }^{12}$. Spostrzeżenie to łączy się z postulatem zdefiniowania nowego trybu lektury tekstu, związanego z poetyką doświadczenia. Jeden z jej wariantów autor Języka modernizmu definiuje jako, ,nadawanie formy bezkształtnemu przeżyciu [...] osadzonemu w progowych, predyskursywnych i przedpojęciowych warstwach doświadczenia"13, kierujące równocześnie uwagę na cielesne i materialne zakorzenienie procesu uczestnictwa w rzeczywistości reprezentowanej

10 Ibidem.

11 Ibidem, s. 7.

12 R. Nycz, Afektywne manifesty, „Teksty Drugie”, 2014, nr 1, s. 7.

13 R.Nycz,Poetykadoświadczenia. Teoria-nowoczesność-literatura, Warszawa2012, s. 148 . 
przez sztukę. Zwrot ku pojęciu doświadczenia łączy się również z badaniami związanymi z szeroko pojmowaną antropologią emocji, znoszącą klasyczną dychotomię pomiędzy czuciem a znaczeniem ${ }^{14}$. Może okazać się ona jednym z możliwych kluczy do interpretacji literatury modernizmu, w której kategoria somy (ciała) łączy się z pojęciem semy (znaku) ${ }^{15}$.

W Powszechnej rozwiazłości Michał Paweł Markowski opisuje możliwość lektury prozy Schulza między innymi w kontekście myśli Gilles'a Deleuze'a. Pisze: „Nietzsche (a chętnie bym to określenie odniósł także do Schulza) jest [...] filozofem czystej immanencji - jakby powiedział [...] Deleuze. Oznacza to - najprościej - że mówiąc o życiu, nie można zająć żadnego stanowiska zewnętrznego wobec życia"16. Jednym z głównych postulatów badacza jest odejście od tradycyjnych wykładni lektury dzieł autora Sklepów cynamonowych na rzecz kategorii związanych z szeroko pojmowaną ,żywą materialnością egzystencji”.

Świat $[\ldots]$ jest wynikiem nieustannego zderzania ludzkich wysiłków formotwórczych z absolutną materią, z życiem - zderzania, w wyniku którego świat ludzki dowodzi swojej niedoskonałości, która dla materii jest nie do zniesienia ${ }^{17}$.

Dla autora Sanatorium pod Klepsydra najistotniejsze staje się ,[...] rozumienie życia, które otwiera się na interpretację dokonywaną z jego wnętrza" ${ }^{18}$. Właśnie w tej próbie dotarcia do „wnętrza życia” dostrzec można związki prozy Schulza z kategorią afektu, ujmującą powstawanie tekstu (i jego interpretację) jako dynamiczny proces odzwierciedlający nurt życia „wykraczającego poza formę" - także formę językową.

14 Por. m.in. J. Leavitt, Znaczenie i czucie $w$ antropologii emocji [w:] Emocje $w$ kulturze, red. M. Rajtar, J. Straczuk, Warszawa 2012, s. 62. Znajdujące swoje różnorodne interpretacje we współczesnej humanistyce pojęcie afektu interpretuję tu za Brianem Massumim. W odróżnieniu od emocji, których reprezentacje są już ustabilizowane społecznie i językowo, afekty należą do sfery „niewysławialnego” i „pierwotnego”; do „migotań” pomiędzy ciałami, sytuując się na granicy tego, co reprezentowalne i niemożliwe do przedstawienia. Por. B. Massumi, Autonomia afektu, przeł. A. Lipszyc, „Teksty Drugie” 2014, nr 1, s. 114. Podobne stanowisko wyraża również Gilles Deleuze: „Afekt nie jest przejściem od jednego stanu przeżytego do innego, lecz nieludzkim stawaniem się człowieka. [...] Jest to raczej ekstremalna styczność w obejmowaniu się dwóch pozbawionych podobieństwa wrażeń [...]. Por. G. Deleuze, F. Guattari, Percept, afekt i pojęcie [w:] iidem, Co to jest filozofia?, przeł. P. Pieniążek, Gdańsk 2010, s. 191.

15 Por. A. Dziadek, Soma i sema - zarys krytyki somatycznej [w:] Literackie reprezentacje doświadczenia, red. W. Bolecki, E. Nawrocka, Warszawa 2007, s. 69.

16 M.P. Markowski, Powszechna rozwiąłość. Schulz, egzystencja, literatura, Kraków 2012, s. 155.

17 Ibidem, s. 173.

18 Ibidem, s. 158. 
Rozpoczynające Sklepy cynamonowe opowiadanie Sierpień otwiera opis scenerii późnego lata, w której narrator, razem z „matką i starszym bratem”, zostaje „wydany na pastwę białych od żaru i oszałamiających dni letnich" ${ }^{19}$. Ta pora roku jest powiązana z powtarzającym się cyklicznie znikaniem postaci ojca: jego „wyjazdem do wód”. Nieobecność ojca posiada, oprócz dosłownej wykładni, również znaczenie symboliczne. Łączy się bowiem z przejęciem dominacji przez matkę, a także służącą, Adelę. Świat kobiet wiąże się z przewagą wrażeń zmysłowych - ,sensorycznych konstelacji” - nad symbolizowanym przez postać Jakuba porządkiem logocentrycznym ${ }^{20}$. Percepcja świata opisywanego w Sierpniu opiera się na sensualnym doświadczeniu „zanurzenia" w przestrzeni późnego lata w niewielkim miasteczku, opisywanym przez ciąg odniesień do sfery Księgi i mitu: pełnej blasku „wielkiej księgi wakacyj”. Adela zostaje porównana przez narratora do Pomony - rzymskiej bogini sadów, wracającej rano z targu i niosącej w swoim koszu owoce: ,[...] tajemnicze czarne wiśnie, $[\ldots]$ morele, w których miąższu złotym był rdzeń długich popołudni” (S, s. 3). Sensualny i liryczny opis „czystej poezji” owoców zostaje w dalszej części skontrastowany z (wywołującą odmienne wrażenie sensoryczne) narracją dotyczącą znajdującego się w koszu mięsa:

[...] obok tej czystej poezji owoców wyładowywała nabrzmiałe siłą i pożywnością płaty mięsa z klawiaturą żeber cielęcych, wodorosty jarzyn, niby zabite głowonogi i meduzy - surowy materiał obiadu o smaku jeszcze nie uformowanym i jałowym, wegetatywne i telluryczne ingrediencje obiadu o zapachu dzikim i polnym (S, s. 3).

Opis „mięsności” materii przeniknięty jest witalizmem: cechuje go sposób obrazowania związany z cielesnością: „siła” i „pożywność”. Łączy się zarówno z przedmiotami - instrumentami muzycznymi (,klawiatura żeber”), jak i metaforyką akwatyczną: (,wodorosty, głowonogi i meduzy - surowy materiał obiadu o smaku jeszcze nie uformowanym i jałowym") (S, s. 3). W przeciwieństwie do owoców kojarzonych z delikatnością, „surowe” mięso i warzywa nasuwają skojarzenia z potwornością i groteską, symbolizowaną przez świat morskich zwierząt. Stają się one hybrydami: wynaturzonymi „gło-

19 B. Schulz, Sierpień [w:] idem, Opowiadania. Wybór esejów i listów, wybór i oprac. J. Jarzębski, Wrocław-Warszawa-Kraków 1998, s. 3. Wszystkie dalsze cytaty pochodzące $\mathrm{z}$ tego wydania oznaczać będę symbolem $\mathrm{S}$, wraz z podaniem numeru strony w nawiasie.

20 Aldona Kopkiewicz określa strategie wykorzystania sensualności w prozie Schulza mianem „sensorycznych konstelacji”. Określenie to oznacza, zdaniem badaczki: „[...] fałdy powstałe w wyniku zmysłowych zdarzeń lub afektywnych fiksacji, wyrastające na przecięciu osobistego doświadczenia i rozpisywanych historii [...]. Ujawniają się one jako konfiguracje słów czy form [...] w niewielkich zgrubieniach, które wybrzuszają tekst. [...] To momenty, w których wybrzmiewa czysta literackość, czysta materialność słowa". Por. A. Kopkiewicz, Rejestry zmysłowości - sensoryczne konstelacje Brunona Schulza [w:] Schulz. Przewodnik „Krytyki Politycznej”, Warszawa 2013, s. 70. 
wonogami”, sytuującymi się na pograniczu realności i fantazji. Ten sygnalizowany już w pierwszym opowiadaniu zabieg pojawiał się będzie w przestrzeni całej prozy Schulza, konstruującej obraz świata pełnego odniesień do „pierwotnych" form życia ${ }^{21}$.

Materia w Sierpniu cechuje się surowością, towarzyszy jej płynność i brak uformowania - równocześnie łączy ona $\mathrm{w}$ sobie (pozornie przeciwstawne) elementy żywiołów ziemi i wody. Kontakt z pierwszym z nich cechuje sensualna fascynacja tym, co już poznane; drugi natomiast przynosi doświadczenie obcości i obrzydzenia. Na zasadzie analogii dwojaka natura zawartości kosza Adeli odzwierciedla ambiwalencję samej postaci kobiety. Figura służącej jest niemal w każdym $\mathrm{z}$ opowiadań utożsamiana zarówno $\mathrm{z}$ boskością $\mathrm{i}$ wzniosłością, jak i sferą erotyzmu, wstrętem oraz przyziemnością. Na łączący się ze sferą różnorodnych doznań zmysłowych dualizm postaci służącej zwraca uwagę Markowski: „Adela jest nie tylko driadą, która stroni od zmysłowej miłości, ale też boginią telluryczną, Tellus Mater, Matką-Ziemią, która w starożytnym Rzymie odpowiada za płodność"22. Bohaterka posiada symboliczną władzę nad światem przedstawionym w Sierpniu: pozornie prozaiczna czynność zaciągania przez nią zasłon $\mathrm{w}$ domu stanowi równoczesne „zaciemnienie” dotychczasowego świata; związanie go z przestrzenią wody i ciemności:

Wtedy barwy schodziły o oktawę głębiej, pokój napełniał się cieniem, jakby pogrążony w światło głębi morskiej, jeszcze mętniej odbity w zielonych zwierciadłach $[\ldots]$ (S, s. 4).

Woda nie jest utożsamiana w Schulzowskim opisie ze sferą czystości i przejrzystości, lecz z „mętnością” i zawieszeniem jednoznacznych sądów na temat świata, odbijającego się w nieprzejrzystych, „zielonych zwierciadłach”. Równocześnie łączą ją szerokie związki z mitem i nieustającą transgresją, tak opisywane przez Mirceę Eliadego:

W wodzie wszystko się „rozpływa”, wszelka forma się „rozpada”, historia „zanika", nic z tego, co zrazu istniało, nie pozostaje po zanurzeniu w wodzie [...]. Zanurzenie - na płaszczyźnie ludzkiej - równa się śmierci, a na płaszczyźnie kosmicznej katastrofie (potop), która periodycznie rozpuszcza świat w pierwotnym oceanie. Wody, rozkładając każdą formę i przekreślając wszelką „historię”, posiadają właściwość oczyszczania, regeneracji i odrodzenia. [...] likwidują historię $\mathrm{i}$ - choćby na moment - wprowadzają pierwotną integralnośćc ${ }^{23}$.

21 Jak zauważa Małgorzata Kitowska-Łysiak, kategoria groteski często łączy się w Sklepach cynamonowych z aluzjami do kultu dionizyjskiego i bakchicznego, stanowiąc odzwierciedlenie mitycznego rytmu cyklu wegetacyjnego. Por. M. Kitowska-Łysiak, Groteska [w:] Słownik schulzowski, red. W. Bolecki, J. Jarzębski, S. Rosiek, Gdańsk 2006, s. 133.

22 M.P. Markowski, Powszechna rozwiąłość..., s. 87.

23 M. Eliade, Traktat o historii religii, przeł. J. Wierusz-Kowalski, Warszawa 2000, s. 213-214. Cyt. za: M. Douglas, Czystość i zmaza, przeł. M. Bucholc, Warszawa 2007, s. 192. 
Dualizm opisu zawartości kosza Adeli oraz opozycji wody i ziemi wyznacza tor dalszej narracji Sierpnia. Opis świata jest tu zarazem cielesny i sensualny oraz usytuowany w sferze mitu; nasuwa skojarzenia z nieposkromioną, witalistyczną bujnością roślinności, związaną z doświadczeniem wstrętu. Ogród posiada cechy przerysowanej, groteskowej kobiecości - narrator pisze o jego „babskiej bujności”, która „[...] rozpanoszyła się płatami włochatych blach listnych, wybujałymi ozorami mięsistej zieleni” (S, s. 7). „Mięsistość zieleni" staje się w tym fragmencie równie istotna, jak przywoływana w poprzednim fragmencie zieleń zwierciadeł. Kolor ten w dosłowny sposób wydaje się powstawać z połączenia barwy żółtej z niebieską - stanowi element pośredni pomiędzy pojawiającymi się $\mathrm{w}$ poprzednich fragmentach opisami słońca i wody. Metafora „bujności życia” łączy się z porównaniem lata do „babsk szeroko rozsiadłych, na wpół pożartych przez swoje oszalałe spódnice" (S, s. 7). Ogród, na zasadzie ciągu asocjacji, staje się targowiskiem, na którym: ,[sprzedawano] [...] za darmo najtańsze krupy dzikiego bzu, śmierdzącą mydłem, grubą kaszę babek, dziką okowitę mięty i wszelką najgorszą tandetę sierpniową" (S, s. 7). Wspominana „tandetność” materii powracać będzie we wszystkich dalszych opowiadaniach ze Sklepów cynamonowych. Motyw śmietnika łączy się zarazem z modernistyczną refleksją nad procesem destrukcji kultury: jak ujmuje to Schulz w eseju Wędrówki sceptyka:

Jak daleko i szeroko okiem sięgnąc - wszędzie gruz i miał. Wędrowiec zastał już wszystko w gruzach, przeorane wzdłuż i w poprzek przez pług niestrudzonej myśli ludzkiej. [...] Tu głowa patrzy z ukosa, tam noga wygrzebuje się i kuśtyka samotnie przez śmietnisko ${ }^{24}$.

24 B. Schulz, Wędrówki sceptyka [w:] idem, Opowiadania..., s. 426. Pojęcie „tandety” stanowi jeden z najistotniejszych elementów opisu stosowanego przez autora Sklepów cynamonowych sposobu opisu materii. Jak zauważa Włodzimierz Bolecki, pojęcie to odnosi się odpowiednio do „ludzi, natury, materii nieożywionej czy materii miasta" (W. Bolecki, Tandeta [w:] Stownik schulzowski, s. 382). W prozie Schulza określają je dwie pozornie różne cechy związane z barwą: z jednej strony, szarość i „wygaszenie”; z drugiej - nadmiar i krzykliwość kolorów. Rodzaj filozoficznego traktatu dotyczącego jej roli w kształtowaniu obrazu materii przedstawia Jakub w trzech częściach Traktatu o manekinach: ,[...] tworzenie jest przywilejem wszystkich duchów. Materii dana jest nieskończona płodność, niewyczerpana moc życiowa i zarazem uwodna siła pokusy, która nas nęci do formowania. [...] Czekając na ożywcze tchnienie ducha, przelewa się ona w sobie bez końca, kusi tysiącem słodkich okrąglizn i miękkości, które z siebie w ślepych rojeniach wymajacza" (B. Schulz, Traktat o manekinach albo wtóra Księga Rodzaju [w:] idem, Opowiadania ..., s. 35). W opowiadaniu Ulica Krokodyli autor Sklepów cynamonowych pisze: „Pseudoamerykanizm, zaszczepiony na starym, zmurszałym gruncie miasta, wystrzelił tu bujną, lecz pustą i bezbarwną wegetacją tandetnej, lichej pretensjonalności. Widziało się tam tanie, marnie budowane kamienice o karykaturalnych fasadach, oblepione monstrualnymi sztukateriami z popękanego gipsu" (B. Schulz, Ulica Krokodyli [w:] idem, Opowiadania ..., s. 76). Zdaniem M.P. Markowskiego, „tandeta” jest elementem ,powszechnej rozwiązłości” materii, opierającej się na dekonstrukcji relacji między formą a jej brakiem; wynikiem przenikania iluzoryczności spod przykrywającej 
Rozpadające się ciała manekinów symbolizują typowe dla literatury modernizmu doświadczenie rozpadu świata i adekwatnego języka jego opisu; równocześnie jednak przedstawiają nietrwałość uchwytnej w sposób zmysłowy materii. Przestrzeń ogrodu tworzy punkt wyjścia do wprowadzenia postaci jednej z głównych bohaterek Sierpnia - chorej psychicznie żebraczki, Tłui. To właśnie w ogrodzie usytuowane jest jej łóżko, którego opis narrator opiera na metaforyce związanej z odpadkami i brudem oraz doświadczeniem „wybrakowania materii":

Na kupie śmieci i odpadków, starych garnków, pantofli, rumowiska i gruzu stało zielono malowane łóżko podparte zamiast brakującej nogi dwiema starymi cegłami (S, s. 7).

Po raz trzeci już - na zaledwie kilku stronach opowiadania - powraca zieleń, tym razem jako barwa ramy zniszczonego łóżka, na którym siedzi kobieta. Opis ten wydaje się antycypować pojawiające się w dalszej narracji doświadczenie wstrętu. Staje się ono jednym z odczuć, dzięki któremu narrator opowiadania - dorastający chłopiec - może skonstruować swój opis porządku świata; podjąć refleksję nad jego symboliczną „geografią”, tym, co ,już poznane” i „wciąż obce”. W eseju Czystość i zmaza Mary Douglas zauważa: „[...] póki nie ma tożsamości, śmieci nie są groźne”. Brud stanowi, zdaniem autorki, ,produkt uboczny tworzenia porządku” i jest zarazem „równie trafnym symbolem narodzin i wzrostu, jak i zniszczenia"25; posiada równocześnie siłę witalną i destrukcyjną. Doświadczenie tej zmienności towarzyszyć będzie opisowi Tłui, która:

[...] siedzi przykucnięta wśród żółtej pościeli i szmat. Wielka jej głowa jeży się wiechciem czarnych włosów. Twarz jej jest kurczliwa, jak miech harmonii. Co chwila grymas płaczu składa tę harmonię w tysiąc poprzecznych fałd, a zdziwienie rozkłada ją z powrotem [...] (S, s. 7).

Twarz bohaterki, podobnie jak opisywane wcześniej „płaty mięsa” w koszu Adeli, zostaje porównana (przez zmienność swojej ekspresji) do muzycznego instrumentu - „miechu harmonii”. Bohaterka reprezentowana jest przez podlegającą nieustannym transformacjom cielesność, stającą się miejscem „przepływu” sprzecznych z sobą (a zarazem typowych dla stanu szaleństwa) reakcji: płaczu i zdziwienia. Ruch twarzy staje się miejscem „odgrywania” intensywności doznań, nieustannego ruchu afektów, niemogących się jednak przekształcić w skonkretyzowane emocje. Przez doświadczenie choroby postać Tłui wykluczona jest z ustalonego porządku społecznego, który w ciągu wieków (na co wskazywał m.in. Michel Foucault) opiera sens swojego istnie-

rzeczywistość fasady (por. M.P. Markowski, Powszechna rozwiązłość..., s. 96). Ujęcie jej jako rodzaju kategorii estetycznej pozwala również określić znaczenie odczucia wstrętu wobec wybrakowanej, „rozsypującej się” materii, co przedstawione zostanie w dalszej części pracy.

25 M. Douglas, op.cit., s. 191. 
nia na tym, co skodyfikowane i zinstytucjonalizowane ${ }^{26}$. Choroba psychiczna wywołuje u bohaterki otwartość na wszelkiego rodzaju zmienność materii, która w Sierpniu - i innych opowiadaniach - staje się dynamiczna, niepoddająca się uchwyceniu i zatrzymaniu. Samo otoczenie, w którym znajduje się Tłuja, wywołuje doświadczenie wstrętu - zabarwiona na żółto pościel zyskuje wymiar abiektywny. Podobny sposób obrazowania pojawia się w dalszym opisie bohaterki. Uwagę w jej twarzy przykuwają: „drobne oczy i wilgotne dziąsła z żółtymi zębami pod ryjowatą, mięsistą wargą" (S, s. 7-8). Epitety związane z „mięsistością” oraz „żółcią” zębów reifikują i animizują bohaterkę; zarazem jednak nabiera ona cech ,pogańskiego bożka”:

[...] na wpół naga i ciemna kretynka dźwiga się powoli i staje, podobna do bożka pogańskiego, na krótkich dziecinnych nóżkach, a z napęczniałej napływem złości szyi, z poczerwieniałej, ciemniejącej od gniewu twarzy, na której jak malowidła barbarzyńskie wykwitają arabeski nabrzmiałych żył, wyrywa się wrzask zwierzęcy, wrzask chrapliwy, dobyty ze wszystkich bronchij i piszczałek tej półzwierzęcej-półboskiej piersi (S, s. 8).

Postać kobiety cechuje groteskowe zderzenie cech ludzkich z cechami zwierzęcymi. Jej ciało staje się hybrydą łączącą w sobie cechy dziecka i dojrzałej kobiety. Szyja Tłui wyraża ciągłe napływy ,intensywności”: pęczniejąc, budzi obrzydzenie i niepokój. Zwierzęcość, kojarzona z boskością, staje się wyrazistym elementem bakchicznego, „pogańskiego kultu”. Bohaterka nie potrafi mówić, co również staje się powodem jej wykluczenia ze społeczności: jedynymi formami ekspresji są „,chrapliwy wrzask”, „ciche zrzędzenie” i „chrząkanie”. Ciało ponownie zostaje porównane do muzycznego instrumentu: „piszczałki piersi” nasuwają skojarzenie z ,przepływem intensywności” dźwięków wydawanych w nieświadomy sposób przez kobietę. Postać Tłui kojarzona jest z kawałkiem mięsa, do którego zlatują się muchy - ,podnoszące się wielkim, huczącym rojem, pełnym wściekłego bzykania, błysków i migotań" (S, s. 8). Bohaterka staje się rządzącą nimi w perwersyjny sposób boginią: postacią pół boską, pół zwierzęcą, boginią płodności, odbywającą pogański, kopulacyjny rytuał z krzewem dzikiego bzu ${ }^{27}$. Opisowi postaci towarzyszy u Schulza opozycja brudu i porządku, które interpretować można w kategoriach „czystości” i „zmazy” opisywanych przez Mary Douglas. W ujęciu badaczki każde działanie związane z wprowadzaniem sfery porządku - zarówno w umyśle, jak i świecie zewnętrznym, łączy się z dwoistością postawy wobec wypieranych elementów: ich równoczesną tabuizacją i rytu-

26 Na temat koncepcji Foucaulta por. m.in.: M. Czerwiński, Wstęp [w:] M. Foucault, Historia szaleństwa w dobie klasycyzmu, przeł. H. Kęszycka, Warszawa 1987, s. 5.

${ }_{27}$ Co interesujące, sam wybór gatunku drzewa towarzyszącego kobiecie również może łączyć się tu ze sferą szaleństwa: Władysław Kopaliński wskazuje gatunek bzu jako podstawę etymologiczną „bzika” (na podobnej zasadzie, co potoczne określenie „fioł” wywodzące się od gatunku kwiatu - fiołka). Por. W. Kopaliński, Bzik [w:] idem, Stownik mitów i tradycji kultury, Warszawa 1985, s. 130. 
alizacją ${ }^{28}$. Opis Tłui, przywołując skojarzenia z monstrualnością i swoistym „wynaturzeniem” cielesności, oddziałuje na czytelnika przez pełen metafor opis barw i wyszczególnionych fragmentów ciała. Odrzuceniu i obrzydzeniu towarzyszy fascynacja postacią kobiety: dostrzeżenie misternej konstrukcji, „arabeski” żył, tworzącej z kobiety rodzaj groteskowego posągu - łamiącego zasady tradycyjnej estetyki ożywionego „dzieła sztuki”.

Podobny sposób obrazowania Schulz wykorzystuje w opisie matki Tłui - Maryśki. Kobieta określana jest przez - groteskowo wyolbrzymioną - perspektywę nieustannie wykonywanych przez nią prac domowych. Uwagę narratora przykuwa żółty odcień jej skóry - jest to równocześnie kolor szafranu, używanego przez Maryśkę do czyszczenia podłóg i mebli. Kolor żółci, w postaci Tłui utożsamiany ze wstrętem, w opisie jej matki łączy się zarówno z czystością, jak i chorobliwie zmienioną barwą skóry. To równocześnie przywoływany już - kolor słońca z pierwszych zdań opowiadania oraz barwa słonecznika rosnącego przy jednej z uliczek:

Ogromny słonecznik, wydźwignięty na potężnej łodydze i chory na elephantiasis, czekał w żółtej żałobie ostatnich, smutnych dni żywota, uginając się pod przerostem potwornej korpulencji (S, s. 6).

Elephantiasis jest określeniem związanym ze szczególną postacią choroby fizycznej: oznacza rozrost tkanki skóry doprowadzający do deformacji różnych kończyn - najczęściej nóg. Chorobliwy „rozrost” kwiatu staje się elementem materii, na którym koncentruje się szczegółowy opis narratora. Położenie postaci kobiet zyskuje analogię do „wielkiej tragedii słonecznika”w Schulzowskim opisie antropomorfizowanego poprzez doświadczenie „niezrozumienia" przez inne kwiaty. Ludzie i rośliny tworzą tu rodzaj wspólnoty, łączącej różnorodne formy „migotliwego” życia, spajanej przez niewyrażalne werbalnie odczucia równoczesnej radości i tragizmu egzystencji. Maryśka, „blada jak opłatek”, porównana jest przez narratora do „rękawiczki, z której wysunęła się dłoń". Metafora ta nasuwa skojarzenia ze starzejącą się rzeczą, która utraciła swoje pierwotne funkcje; niepotrzebnego elementu i resztek dawnej, żywej materii. Podobnie jak jej córka, kobieta pozbawiona jest umiejętności mowy - komunikuje się przez ekspresję wyrażalną w przestrzeni koloru: zamiast Maryśki ,gadała cisza, żółta, jaskrawa” (S, s. 9). Choroba psychiczna kobiety ma wpływ na wypowiadane przez nią słowa: „głośny i ordynarny maniacki monolog". Bohaterka znajduje się poza sferą Logosu; podobnie jak chrapliwe dźwięki wydawane przez Tłuję, jej „monolog” staje się zapisem napięcia konstruowanego w relacji ze światem.

W szkicu Wariatka na śmietniku. „Sierpień” Brunona Schulza Ewa Świąc interpretuje postać Tłui w kontekście pracy Madwoman in the Attic autorstwa

28 Por. J. Tokarska-Bakir, Energia odpadków [w:] M. Douglas, Czystość i zmaza, s. 32. 
Sandry Gilbert i Susan Gubar ${ }^{29}$. Stanowiąca jeden z kluczowych toposów krytyki feministycznej postać „wariatki na strychu” symbolizuje stłumienie i wyparcie z kobiecej codzienności sfery szaleństwa, sytuującej się w przestrzeni metaforycznego „strychu”, do którego dostęp zostaje „zablokowany”. Choć rozpoznania obu autorek dotyczą przede wszystkim postaci kobiety - pisarki, „wariatka” staje się zarazem metaforą „kobiecego uwięzienia” w fallogocentrycznej sferze czystego Logosu. Zdaniem Świąc, figura piszącej miałaby ,[...] reprezentować cielesność samospełnioną, samowystarczalną, niezależną"30. Funkcję strychu przejmuje w opowiadaniu Schulza śmietnik - dodatkowo „stygmatyzujący” postać kobiety przez związki z brudem i obrzydzeniem. Tłuja reprezentuje to, co wyparte i nieświadome, niepoddające się słownej artykulacji. W świetle powyższych rozpoznań staje się postacią odzwierciedlającą sferę abiektu: deprecjonowaną i odsyłaną do sfery nieświadomości. Interpretując topos „wariatki na strychu”, Krystyna Kłosińska zauważa:

[...] kobieta - potwór [...] uosabia pewność siebie, agresywność, a przede wszystkim niezależność. Jako figura męskiego tekstu stanowi zapis lęku autora przed utratą choćby części przynależnej mu władzy i autorytetu. [...] Odmawia pozostawania w narzucanym jej tekstowo miejscu [...], próbując wytwarzać swoją własną historię i nadawać jej własne znaczenie ${ }^{31}$.

Wydaje się jednak, że Tłuja i jej matka są nie tylko figurami mogącymi wyrażać opisywaną przez krytykę feministyczną sferę męskiego „pierwotnego lęku". Równie istotna staje się tutaj rozwijana na różne sposoby metaforyka związana z doświadczeniem obrzydzenia - oraz erotyczna fascynacja kobiecą „bujnością” i sferą szaleństwa, widoczną w wyrazisty sposób nie tylko w tekstach, ale i grafikach Schulza - zwłaszcza Xiędze Bałwochwalczej. Widoczne jest to zwłaszcza w trzecim podrozdziale Sierpnia, rozpoczynającym się od wizyty narratora u ciotki Agaty. Opis samej bohaterki poprzedzony zostaje zwróceniem uwagi na „bujną zieleń ogródka” oraz stojące przy wejściu do domu „kolorowe szklane kule”, porównane do baniek mydlanych, „w których zaklęte były całe świetlane i jasne światy" (S, s. 9). Dom ciotki oddziałuje na narratora w sensualny sposób:

$\mathrm{W}$ tej zaufanej starej woni mieściło się w dziwnie prostej syntezie życie tych ludzi, alembik rasy, gatunek krwi i sekret ich losu, zawarty niedostrzegalnie w codziennym mijaniu ich własnego, odrębnego czasu (S, s. 9).

Opis przedmiotów znajdujących się w domu w płynny sposób przechodzi w charakterystykę ciotki: „Spod ściany podniosła się ciotka Agata, wielka i bujna, o mięsie delikatnym i bladym, cętkowanym rudą rdzą piegów" (S, s. 10).

29 E. Świąc, Wariatka na śmietniku. Sierpień Brunona Schulza [w:] Białe plamy w schulzologii, red. M. Kitowska-Łysiak, Lublin 2010, s. 216.

30 Ibidem, s. 219.

31 K. Kłosińska, Lęk przed wariatka na strychu (z wprowadzeniem A. Gajewskiej), „Przekładaniec” 2010, nr 24, s. 240. 
Postać Agaty podlega procesowi reifikacji - jej cielesność zostaje uprzedmiotowiona. Narrator Sierpnia ponownie odwołuje się do kategorii „mięsności”, pojawiającej się już w opisie kosza niesionego przez Adelę. Podobnie jak w opisie Tłui i jej matki, istotniejszy od samego znaczenia słów wypowiadanych przez Agatę staje się sposób ich artykulacji - dźwięk, ton i barwa głosu: „Ciotka narzekała. Był to zasadniczy ton jej rozmów, głos tego mięsa bladego i płodnego, bujającego już jakby poza granicami osoby [...]” (S, s. 10). „Mięsność”, budząca wstręt i fascynację, „wykracza poza granice osoby” - staje się doświadczeniem spotkania ze sferą abiektu. Agatę cechuje „wybujała kobiecość, spychająca na margines wuja Marka" - męża bohaterki. Figura mężczyzny, realizując stały topos podległości obecny w prozie i grafikach autora Sklepów cynamonowych ${ }^{32}$, zostaje odsunięta na drugi plan - bohater pozbawiony jest $\mathrm{w}$ wyrazisty sposób towarzyszącej postaci kobiety witalnej energii: „mały, zgarbiony, o twarzy wyjałowionej z płci, siedział w swym szarym bankructwie, pogodzony z losem, w cieniu bezgranicznej pogardy, w którym zdawał się wypoczywać” (S, s. 10). Jedynym „przebłyskiem” życia stają się oczy mężczyzny, w których czasami „tli się daleki żar ogrodu, rozpięty w oknie" (S, s. 10). To właśnie cechujący się bujnością ogród stanowi jeden z niewielu symboli „siły życia” w opowiadaniu - przeciwstawionej „nieruchomości” i „senności” domowych wnętrz. Dominująca nad mężem w sposób fizyczny i psychiczny Agata zostaje utożsamiona z kobiecą płodnością; „rozpustnym dzieworództwem" kobiecości. Metafora ta skonstruowana jest na zasadzie paradoksu: dzieworództwo (partogeneza) oznacza proces rozwoju organizmu bez udziału męskiej komórki, często spotykany w świecie bezkręgowców, ryb, gadów oraz niektórych gatunków ptaków. Próba zastosowania tego określenia w odniesieniu do człowieka przedstawia zarazem ambiwalencję stosunku narratora do kobiecości. Pierwotna dziewiczość łączy się w niej z rozpustą i orgiastycznym „szałem” cielesności; zarazem to, co ludzkie, zrównane zostaje przez proces swojego „rozrostu” z tym, co zwierzęce. Tym samym seksualność Agaty budzi w narratorze Sierpnia zarówno wstręt, jak i fascynację. W opisie kobiecej dominacji powraca metaforyka związana z chorobą i wybrakowaniem, z cechującą świat roślin i zwierząt „wybujałością”. Egzysten-

32 Wątek ten był już wielokrotnie komentowany przez interpretatorów prozy i grafik autora Sierpnia. Artur Sandauer uznawał postawę masochistyczną za jeden z podstawowych elementów Schulzowskiej filozofii twórczości, dotyczącej problematyki nie tylko erotycznej, lecz także społecznej oraz estetycznej. „Degradacja” postaci mężczyzny staje się tu zarazem „degradacją rzeczywistości”; uznaniem stosunków niższości kształtującej relacje międzyludzkie. Por. A. Sandauer, Rzeczywistość zdegradowana (Rzecz o Brunonie Schulzu) [w:] B. Schulz, Proza, Kraków 1973. Obrazy mężczyzn podlegających erotycznej kobiecej dominacji obecne są niemal w każdym szkicu pochodzącym z Xięgi Bałwochwalczej. Kobiety przedstawiane były w grafikach autora Sklepów cynamonowych jako rządzące mężczyznami boginie, których postacie często stanowiły nawiązania do elementów mitologii greckiej - tak jak w szkicach Bachanalia czy Panna Hestia. Na ten temat por. m.in. J. Gondowicz, Piękno adeliczne [w:] idem, Trans-Autentyk. Nie-czyste formy Brunona Schulza, Warszawa 2014, s. 73. 
cja Agaty zyskuje przez to, na podobnej zasadzie co życie kwiatu, wymiar zarazem groteskowy i tragiczny: ,[...] było coś tragicznego w tej płodności niechlujnej i nieumiarkowanej, był jakiś heroizm kobiecości triumfującej urodzajnością nad kalectwem natury, nad insufficencją mężczyzny" (S, s. 11). Opis ten, przez groteskową hiperbolizację modernistycznego mitu „kobiety fatalnej", prowadzi do równoczesnego zintensyfikowania i przekreślenia tego motywu. Dojmująca siła kobiecości przez nadmiar swojego „urodzaju” dąży w stronę reifikacji i samounicestwienia, pozbawiających ją w paradoksalny sposób pełni siły sprawczej.

Młodszą z kobiet, zamieszkującą dom ciotki Agaty, jest Łucja: ,„[... średnia, z głową nazbyt rozkwitłą i dojrzałą na dziecięcym i pulchnym ciele o mięsie bladym i delikatnym" (S, s. 11). Postać dorastającej dziewczyny cechuje niedopasowanie „nazbyt rozkwitłej” głowy do reszty ciała, porównanego do „bladego i delikatnego mięsa”. „Blade”, ,płodne” i , delikatne” mięso obu kobiet nie budzi równie silnych doświadczeń sensualnych jak mięso w koszu Adeli: nie jest kojarzone również ze zwierzęcością Tłui, a raczej z , ,udomowioną" sferą kobiecej płodności: nie pełnej i dojrzałej, jak u ciotki Agaty, ale dopiero się zarysowującej. Obie postacie konstruowane są na zasadzie groteskowego przejaskrawienia, ,niedopasowania” poszczególnych członków ciała lub ich hiperbolizacji, nadmiernej „wybujałości”. Zauważyć można, że kobiecość nigdy nie łączy się w Sierpniu z normą - cechuje ją rozrost i nadmiar, bądź też, jak w postaci Maryśki, stopniowe „odcieleśnienie”, brak i zanikanie.

Swoisty kontrapunkt dla postaci pięciu kobiet - Adeli, Tłui, Maryśki, Agaty i Łucji - stanowi zamykający Sierpień opis najstarszego kuzyna - Emila. Postać mężczyzny opiera się na „wycofaniu z życia” oraz uległości, cechujących także męża ciotki Agaty. „Nagie życie”, odzwierciedlane na różne sposoby przez wszystkie kobiety, w opisie Emila całkowicie zanika: narrator widzi go siedzącego ,[...] z jasnoblond wąsem, z twarzą, z której życie zmyło jakby wszelki wyraz" (S, s. 11). Domenę kobiet stanowią hiperbolizowane opisy ich budzącego wstręt witalizmu i aktywności; w postaciach mężczyzn natomiast, siły te ujawniają się poprzez ,przebłysk intensywności”, który po chwili gaśnie i zatraca się w sferze dnia codziennego, zdominowanej przez kobiecość. Charakter Emila ujawnia w największej mierze jego ubranie: „strój elegancki i drogocenny”. Mężczyzna wydaje się „wtapiać” w otaczające go tło domu: „Jego twarz zwiędła i zmętniała zdawała się z dnia na dzień zapominać o sobie, stawać się białą pustą ścianą z bladą siecią żyłek" (S, s. 11). Postaci Emila daleko do intensywności życia wyrażającej się, jak u Tłui, w „pulsujących żyłach”. Posiada ona jednak pewne ,przebłyski” dawnego życia: „,...] jak linie na zatartej mapie, plątały się gasnące wspomnienia tego burzliwego i zmarnowanego życia" (S, s. 11). Podobnie jak w opisie Maryśki, Schulz stosuje zabieg reifikacji, polegający na „wyłączeniu” sił witalnych z opisywanej osoby - obserwując Emila, narrator Sierpnia zauważa: „Zdawało się, że to ubranie samo leży, fałdziste, zmięte, przerzucone przez fotel” (S, s. 12). Mężczyzna wydaje się pozbawiony życia (,wygasły”), a jedynym prze- 
błyskiem jego „intensywności” staje się mruganie okiem w stronę narratora. W tym drobnym geście twarz mężczyzny oprócz zaciekawienia budzi również obrzydzenie: „Z mgły twarzy wyłoniło się z trudem wypukłe bielmo bladego oka, wabiąc mnie figlarnym mruganiem" (S, s. 12). Emil wprowadza narratora w dwuznaczną sytuację oglądania pornograficznych zdjęć: „Wziął mnie między kolana i tasując przed mymi oczyma wprawnymi dłońmi fotografie, pokazywał wizerunki nagich kobiet i chłopców w dziwnych pozycjach" (S, s. 12). Działaniu temu towarzyszą zarówno budowanie napięcia, jak i jego nagły zanik, tworzące wspólnotę między mężczyznami, opartą na kontakcie z pozbawioną słownego komentarza erotyką: ,[...] fluid niejasnego wzburzenia, którym nagle zmętniało powietrze, doszedł do mnie i zbiegł mnie dreszczem niepokoju, falą nagłego zrozumienia" (S, s. 12). To właśnie erotyzm staje się siłą życiową nadającą sens obecności Emila: „natężenie[m], trzymając[ym] przez chwilę jego rysy w skupieniu". Twarz mężczyzny - podobnie jak wizerunki pozostałych bohaterów Sierpnia - przypomina rodzaj maski, na której rysują się groteskowo przekształcone doświadczenia różnorodnych odczuć. Podobną strategię autor Sklepów cynamonowych stosuje w opisie przechodniów na ulicy:

Przechodnie, brodząc w złocie, mieli oczy zmrużone od żaru, jakby zalepione miodem, a podciągnięta górna warga odsłaniała im dziąsła i zęby. I wszyscy brodzący w tym dniu złocistym mieli ów grymas skwaru, jak gdyby słońce nałożyło swym wyznawcom jedną i tę samą maskę - złotą maskę bractwa słonecznego; i wszyscy, którzy szli dziś ulicami, spotykali się, mijali, starcy i młodzi, dzieci i kobiety, pozdrawiali się w przejściu tą maską, namalowaną grubą, złotą farbą na twarzy, szczerzyli do siebie ten grymas bakchiczny - barbarzyńską maskę kultu pogańskiego (S, s. 4).

„Odsłonięcie” zębów i dziąseł związane jest z groteskowym wykrzywieniem twarzy mieszkańców miasteczka. Metafora „bakchicznego grymasu” łączy codzienność z mitem; równocześnie jednak odsyła do sfery głębokiej pierwotności; „pogańskiego kultu”, obecnego również w przywoływanym już opisie Tłui. Pojawiający się w poprzednich opisach kobiet kolor żółty nabiera w powyższym fragmencie uszlachetnionej „barwy złota”. Odsłonięcie dziąseł wysuwa na pierwszy plan „mięsność” ciała, zaskakującego i budzącego obrzydzenie przez kontrast $\mathrm{z}$ pozornym dostojeństwem przybieranych przez przechodniów „masek”, przywodzących na myśl spektakl teatralny. Markowski uznaje tę cechę za jedną z podstaw Schulzowskiej wyobraźni: zdaniem badacza, jednocześnie „tekstualnej” $i$,teatralnej”. Sama rzeczywistość okazuje się tu zarazem „tekstem do interpretacji”, jak i „teatralnym spektaklem”"33. Opisom przyrody towarzyszy w Sierpniu nieustanne przejaskrawienie i dekoracyjność. Podobnie jak „maski” przechodniów, zyskuje ona niemal erotyczny powab przez swoją sztuczność: „Zdawało się, że te drzewa afektują wicher,

33 M.P. Markowski, Polska literatura nowoczesna. Leśmian, Schulz, Witkacy, Kraków 2007, s. 261. 
wzburzając teatralnie swe korony, ażeby w patetycznych przegięciach ukazać wytworność wachlarzy listnych o srebrzystym podbrzuszu, jak futra szlachetnych lisic" (S, s. 4-5). Wykorzystany w tym miejscu czasownik ,afektują" sugeruje cechy nienaturalności i przesady; równocześnie jednak w swoim pierwotnym znaczeniu, „afektować” oznacza „pragnąć, pożądać”, „afektowany” natomiast, to inaczej: „przesadny, egzaltowany”34. Określenia te, nasuwając skojarzenia z pozornością opisywanych zjawisk, mogą stanowić równocześnie komentarz do opisywanej powyżej poetyki całego opowiadania, realizującej się w przestrzeni zawiązującej się między bohaterami i przedmiotami „intensywności”. „Napięcia” tworzące się pomiędzy osobami, zwierzętami i światem przyrody odsłaniają ich „teatralną” dekoracyjność; dwuznaczność; „lichotę" i „tandetę" kryjącą się za pozornie stałymi fasadami.

W podobny sposób konstruowany jest pojawiający się w Sierpniu opis ogrodu:

Splątany gąszcz traw, chwastów, zielska i bodiaków buzuje w ogniu popołudnia. Huczy rojowiskiem much popołudniowa drzemka ogrodu. Złote ściernisko krzyczy w słońcu, jak ruda szarańcza; w rzęsistym deszczu ognia wrzeszczą świerszcze; strąki nasion eksplodują cicho, jak koniki polne [...] (S, s. 7).

Przestrzeń odzwierciedlona zostaje przez sferę różnorodnych dźwięków: „buzowanie, huk, krzyk, wrzask i eksplozję”. Materia konstruująca świat przedstawiony opiera swoje istnienie na nieustannych „wyładowaniach energii”, kształtujących złożone relacje pomiędzy światem ludzkim i „nie-ludzkim”. Wstręt podszyty jest elementami silnej sensualnej fascynacji „tellurycznymi ingrediencjami" przedstawionego w opowiadaniu świata; staje się dominującym doświadczeniem, kwestionującym ustalone przekonania na temat rzeczywistości oraz wpływającym na literacki sposób jej reprezentacji.

Pojawiający się w Sierpniu opis ogrodu warto porównać z analogicznym fragmentem pochodzącym z opowiadania Pan:

Był to najdalszy przylądek, Gibraltar tego podwórza, bijący rozpaczliwie głową w ślepy parkan z poziomych desek, zamykającą i ostateczną ścianę tego świata. Spod jego omszonych dyli wyciekała strużka czarnej, śmierdzącej wody, żyła gnijącego, tłustego błota, nigdy nie wysychająca - jedyna droga, która poprzez granice parkanu wyprowadzała w świat ${ }^{35}$.

Autor Księgi posługuje się w swojej narracji całą gamą epitetów związanych z doświadczeniem rozpadu i obrzydzenia: „omszony”, „czarny”, „śmierdzący”, „gnijący” i „tłusty”. W topografii miasta opisywanego w Sklepach cynamonowych ogród zajmuje jedno z najbardziej odległych miejsc: to "Gibraltar”, miejsce skrajne i tajemnicze. Materia ogrodu staje się wstrętna,

34 Por. hasło: afektować [w:] Słownik języka polskiego PWN, http://sjp.pwn.pl/ slowniki/afektować.html [dostęp: 14.06.2015].

35 B. Schulz, Pan [w:] idem, Opowiadania ..., s. 54. Wszystkie dalsze cytaty pochodzące $\mathrm{z}$ tego wydania oznaczam symbolem $\mathrm{P}$, wraz z podaniem numeru strony $\mathrm{w}$ nawiasie. 
odchodząc od czystego witalizmu prezentowanego w Sierpniu - w symboliczny sposób żółć ustępuje tu miejsca czerni. Doświadczeniem łączącym się z obrzydzeniem jest rozpacz, posiadająca potężną siłę sprawczą i w paradoksalny sposób „otwierająca” spojrzenie na świat:

[...] rozpacz smrodliwego zaułka tak długo biła głową w tę zaporę, aż rozluźniła jedną z poziomych, potężnych desek (P, s. 54-55).

Okno zostaje „otwarte na słońce”, a narrator opowiadania, dorastający chłopiec, odkrywa w towarzystwie kolegów przestrzeń wielkiego ogrodu, ukrytego za opuszczonym zaułkiem. Opis roślin skontrastowany zostaje z niepokojącym opisem zagłębiania się w coraz ciemniejsze rejony ogrodu:

Ale w miarę, jak opadał w głąb długiej odnogi i zanurzał się w cień między tylną ścianę opuszczonej fabryki wody sodowej a długą walącą się ścianę stodoły, wyraźnie pochmurniał, stawał się opryskliwy i niedbały, zapuszczał się dziko i niechlujnie, srożył się pokrzywami, zjeżał bodiakami, parszywiał chwastem wszelkim, aż w samym końcu między ścianami, w szerokiej prostokątnej zatoce tracił wszelką miarę i wpadał w szał. Tam to nie był już sad, tylko paroksyzm szaleństwa, wybuch wściekłości, cyniczny bezwstyd i rozpusta [...] (P, s. 56).

Ulegający antropomorfizacji ogród opisywany jest za pomocą szerokiego spektrum różnorodnych negatywnych odczuć związanych z metaforyką „,ienia”. Od „spochmurnienia”, narrator w płynny sposób przechodzi do „opryskliwości” i „parszywienia”, aby wreszcie, na zasadzie gradacji, wyrażać istnienie roślinności w „paroksyzmie szaleństwa”, „,bezwładzie” i „rozpuście”. Zrozumienie świata natury odbywa się przez włączenie we wspólnotę zmysłowych doświadczeń, zawiązywaną pomiędzy człowiekiem a roślinami. Wyobraźnia narratora - małego chłopca - postrzega to doświadczenie jako coś fascynującego, rozbudzającego naturalną ciekawość zjawisk. Sfera roślinności przechodzi w płynny sposób w przestrzeń erotyczną, nasuwając skojarzenia z rozkoszą. „Kapusty łopuchów” - łopianów, są porównywane do „spódnic wiedźm", w szaleńczy sposób epatujących siłą płodności i kobiecym erotyzmem. Opisowi roślinności towarzyszy metaforyka związana z ciągłym przyrostem materii. Lato jest dla narratora doświadczeniem pełnym zmysłowej intensywności, „natężenia zmysłów”, dzięki któremu elementy rzeczywistości stają się uchwytne w „cielesny” sposób:

O tej godzinie opanowywał mnie szał łowienia motyli, pasja ścigania tych migocących plamek, tych błędnych, białych płatków, trzęsących się w rozognionym powietrzu niedołężnym gzygzakiem. I zdarzyło się wówczas, że któraś z tych jaskrawych plamek rozpadła się w locie na dwie, potem na trzy - i ten drgający, oślepiająco biały trójpunkt wiódł mnie, jak błędny ognik, przez szał bodiaków, palących się w słońcu (P, s. 56-57).

Piotr Millati, analizując znaczenie symboliki motyla w prozie Schulza, za najistotniejszy uznaje w niej trop metamorfozy, przedstawiający owada 
jako symbol duszy i zmartwychwstania ciała. Równocześnie jednak - tak jak w opowiadaniu Wiosna - motyl symbolizować może ciemne sfery egzystencji oraz, jak pisze badacz, wybujałą egzotykę i ,degradującą" sferę erotyki ${ }^{36}$. „Oślepiająca biel" motyla wyraża doświadczenie intensywności i szaleństwa, staje się „błędnym ognikiem” kierującym narratora na określony trop. Równocześnie nasuwa skojarzenia z cechującym długotrwałe wpatrywanie się w słońce doświadczeniem powidoku. Motyl staje się metaforą otępienia i równoczesnego wyostrzenia zmysłu wzroku - oraz pozostałych zmysłów - przez palące słońce, pojawiające się również w Sierpniu. To właśnie motyl wskazuje narratorowi ,głuche zapadlisko”, w którym znajduje się tytułowy „Pan” - drohobycki włóczęga:

Wtedy nagle ujrzałem go. Zanurzony po pachy w łopuchach, kucał przede mną. Widziałem jego grube bary w brudnej koszuli i niechlujny strzęp surduta. Przyczajony jak do skoku, siedział tak z barami jakby wielkim ciężarem zgarbionymi. Ciało jego dyszało z natężenia, a z miedzianej, błyszczącej w słońcu twarzy lał się pot. Nieruchomy, zdawał się ciężko pracować, mocować się bez ruchu z jakimś ogromnym brzemieniem (P, s. 57).

Postać mężczyzny budzi w narratorze uczucie niepokoju i obrzydzenia. Podstawową cechą opisu jest intensywność, określana jako szczególne „natężenie”. Jego wzrok jest silny i przeszywający - jak określa to narrator, „ujmujący w kleszcze".

I nagle z tych rysów, naciągniętych do pęknięcia wyboczył się jakiś straszny, załamany cierpieniem grymas, i ten grymas rósł, brał w siebie tamten obłęd i natchnienie, pęczniał nim, wybaczał się coraz bardziej, aż wyłamał się ryczącym, charczącym kaszlem śmiechu (P, s. 57).

Śmiech nie stanowi w tym przypadku wyzwolenia emocji - jest ono tylko pozorne, nasuwa skojarzenia $\mathrm{z}$,niesamowitością?" $\mathrm{i}$ chorobą. Cierpienie przekształca się w postaci Pana w śmiech, przez który mężczyzna poddawany jest groteskowej deformacji. Cechuje go ,pusta ekspresja”; równoczesne działanie zmysłów i ich wyłączenie:

Czarne oczy wbiły się we mnie z natężeniem najwyższej rozpaczy czy bólu. Te oczy patrzyły na mnie i nie patrzyły, widziały mnie i nie widziały wcale. Były to pękające gałki, wytężone najwyższym uniesieniem bólu albo dziką rozkoszą natchnienia (P, s. 57).

Rozpacz i ból łączą się z sobą - doświadczenie to zyskuje jednak swoje uzasadnienie dopiero $\mathrm{w}$ ostatnich słowach opowiadania. „Dzika rozkosz natchnienia" wynika z przyziemnej czynności fizjologicznej - okazuje się, że mężczyzna oddaje się w zaroślach procesowi defekacji. Wstręt nieustannie obecny w otwierających opowiadanie zdaniach zostaje uzasadniony przez

36 P. Millati, Motyl [w:] Stownik schulzowski, s. 225-227. 
- niewyrażoną wprost - sferę ekskrementów. Bohater, upodobniony do postaci mitycznej, nabiera jednak poprzez kontakt z tą sferą wymiaru boskości, a wydalanie staje się rodzajem jej paradoksalnej emanacji, w której to, co nieczyste, staje się uświęcone - jak pisze Mary Douglas: „nieczystość może być wykorzystywana w obrzędach odnowienia" ${ }^{37}$. Twarz Pana - i cechujący ją grymas - stają się miejscem zapisu przepływu różnorodnych krótkotrwałych ekspresji. Bohater porównywany jest do zwierzęcia - zauważony, ucieka „zgarbiony jak goryl” jako „pan bez fletu, cofający się w popłochu do swych ojczystych kniei”. Doświadczenie obrzydzenia staje się „klamrą” spajającą całe opowiadanie - przechodzące od opisu ogrodu do opisu postaci, oscylujące między fascynacją i wstrętem. Granica między naturą a kulturą staje się tu jednak bardzo płynna; ulega nieustannemu zachwianiu, a podstawowym narzędziem jej konstrukcji stają się „,przepływy” intensywności, zachodzące pomiędzy poszczególnymi elementami ożywionej i nieożywionej materii.

Krzysztof Stala za jeden z głównych kontekstów twórczości autora Sklepów cynamonowych uznaje (inspirowaną filozofią Jacques'a Derridy) sytuację rozpostarcia pomiędzy „,entrum” a „peryferiami”, zawieszającą referencyjny charakter rzeczywistości ${ }^{38}$. Jedną z podstaw jej interpretacji staje się opozycja między mimesis a anty-mimesis - prawdą a fikcjonalnością ${ }^{39}$. Schulzowską filozofię twórczości badacz porównuje z fragmentem Dissemination:

Teoretyczny namysł powinien zawiesić, lub w każdym razie sproblematyzować, [...] naiwne otwarcie, które kiedyś połączyło tekst z jego rzeczą, odniesieniem, treścią, rzeczywistością; czy raczej z jaką́s konkretną powieściową lub semantyczną substancją ${ }^{40}$.

Widoczne w przestrzeni Sklepów cynamonowych „gry” z kategorią mimesis często związane są z podlegającą metamorfozom cielesnością, stanowiącą jedno ze źródeł modernistycznego doświadczenia „wykroczenia poza formę"41. „Odseparowanie” słów od ich pierwotnego znaczenia pozwala zarazem dostrzec elementy do tej pory marginalizowane w większości analiz - między innymi obecne w prozie Schulza literackie reprezentacje stanów afektywnych. Charakter rzeczywistości oparty na „opozycjach” polega tu na dostrzeżeniu „drgań i wibracji materii” ${ }^{\prime 2}$ - jak pisze Stala:

Schulzowska materia realizuje się w najbardziej powszednich wcieleniach sukno ze sklepu ojca, drewno żyjące w meblach, zielsko rozpleniające się na po-

37 M. Douglas, op.cit., s. 194.

38 K. Stala, Na marginesach rzeczywistości. Paradoksy przedstawień w twórczości Brunona Schulza, Warszawa 1995, s. 17.

39 Ibidem, s. 28.

40 J. Derrida, Dissemination, przeł. (ang.) B. Johnson, Chicago 1981, s. 43. Cyt. za: K. Stala, op.cit., s. 30.

${ }^{41}$ K. Stala, op.cit., s. 61.

42 Ibidem, s. 34. 
dwórzu, orzech czy kasztan. Zostaje wyprowadzona z abstrakcyjnej pojęciowości estetyki i filozofii, wnikając w poetyckie obrazy, wydobywające jej gęstość, substancjalność, skupienie. To zawsze materia ,ze śladami walki”, ugniatana i gwałcona, wybuchająca i ,kaleczona” ludzką formą, nadającą jej kształt³.

„Substancjalna”, a zarazem „okaleczona” materia budzi w twórczości autora Wiosny ,podszytą fascynacją” awersję, mogącą podlegać złożonej interpretacji. Opowiadania Sierpień i Pan przedstawiają różnorodne odsłony doświadczenia wstrętu, koncentrując się na próbie wpisania tegoż doświadczenia w topografię specyficznego uniwersum, obejmującego centrum i peryferie, przestrzeń miasta, ogrodu oraz domu. Schulzowską „filozofię wstrętu” cechuje modernistyczna świadomość istnienia niepoznanej ,podszewki” rzeczywistości, wymykającej się próbom jednoznacznej klasyfikacji. Literatura staje się przez to sposobem wyrażenia wszystkich możliwych form „fluidów życia": objawiającego się w pełni swoich sił i możliwości, ale także podlegającego deformacji i destrukcji. Doświadczenie wstrętu, widoczne w tekstowych „napięciach”, staje się narzędziem konstruowania narracji i tożsamości bohaterów opowiadań, łącząc w sobie komizm i powagę, grozę i fascynację. Wstręt może być tu zatem określany mianem doświadczenia granicznego, nieustannie podważającego pewny status ontologiczny bohaterów i wpływającego na ich relacje ze światem.

\section{Bibliografia}

Ahmed S., Performatywność obrzydzenia, przeł. A. Barcz, „Teksty Drugie” 2014, nr 1. Czerwiński M., Wstęp [w:] M. Foucault, Historia szaleństwa $w$ dobie klasycyzmu, przeł. H. Kęszycka, Warszawa 1987.

Deleuze G., Guattari F., Percept, afekt i pojęcie [w:] iidem, Co to jest filozofia?, przeł. P. Pieniążek, Gdańsk 2010.

Douglas M., Czystość i zmaza, przeł. M. Bucholc, Warszawa 2007.

Dziadek A., Soma i sema - zarys krytyki somatycznej [w:] Literackie reprezentacje doświadczenia, red. W. Bolecki, E. Nawrocka, Warszawa 2007.

Foucault M., Historia szaleństwa $w$ dobie klasycyzmu, przeł. H. Kęszycka, Warszawa 1987.

Gondowicz J., Piękno adeliczne [w:] idem, Trans-Autentyk. Nie-czyste formy Brunona Schulza, Warszawa 2014.

Kłosińska K., Lęk przed wariatka na strychu (z wprowadzeniem A. Gajewskiej), „Przekładaniec” 2010, nr 24.

Kopaliński W., Bzik [w:] idem, Słownik mitów i tradycji kultury, Warszawa 1985.

Kopkiewicz A., Rejestry zmystowości - sensoryczne konstelacje Brunona Schulza [w:] Schulz. Przewodnik „, Krytyki Politycznej”, Warszawa 2013.

Kristeva J., Potęga obrzydzenia. Esej o wstręcie, przeł. M. Falski, Kraków 2007.

\footnotetext{
43 Ibidem, s. 36.
} 
Leavitt J., Znaczenie $i$ czucie $w$ antropologii emocji [w:] Emocje $w$ kulturze, red. M. Rajtar, J. Straczuk, Warszawa 2012.

Markowski M.P., Polska literatura nowoczesna. Leśmian, Schulz, Witkacy, Kraków 2007.

Markowski M.P., Powszechna rozwiązłość. Schulz, egzystencja, literatura, Kraków 2012.

Massumi B., Autonomia afektu, przeł. A. Lipszyc, „Teksty Drugie” 2014, nr 1.

Menninghaus W., Wstręt. Teoria i historia, przeł. G. Sowinski, Kraków 2009.

Nycz R., Afektywne manifesty, „Teksty Drugie” 2014, nr 1.

Nycz R., Poetyka doświadczenia. Teoria - nowoczesność - literatura, Warszawa 2012.

Sandauer A., Rzeczywistość zdegradowana (Rzecz o Brunonie Schulzu) [w:] B. Schulz, Proza, Kraków 1973.

Schulz B., Opowiadania. Wybór esejów i listów, wybór i oprac. J. Jarzębski, Wrocław -Warszawa-Kraków 1998.

Stownik języka polskiego PWN, http://sjp.pwn.pl/slowniki/afektować.html [dostęp: 14.06.2015].

Słownik schulzowski, red. W. Bolecki, J. Jarzębski, S. Rosiek, Gdańsk 2006.

Stala K., Na marginesach rzeczywistości. Paradoksy przedstawień w twórczości Brunona Schulza, Warszawa 1995.

Świąc E., Wariatka na śmietniku. „Sierpień” Brunona Schulza [w:] Białe plamy w schulzologii, red. M. Kitowska-Łysiak, Lublin 2010. 